\title{
RECUPERATION OF ENERGY IN THE PNEUMATIC DRIVE OF THE FUNCTIONAL MECHATRONIC MODULE OF ACCUMULATION OF LAYER OF CARGO
}

\author{
M. Iakymchuk, O. Gavva, L. Kryvoplias-Volodina, V. Yakymchuk \\ National University of Food Technologies
}

\begin{tabular}{l} 
Key words: \\
Palletizer \\
Mechatronic module \\
Accumulator \\
Recuperation \\
Energy \\
Pneumatic drive unit \\
Load \\
\hline
\end{tabular}

Article history:

Received 14.11.2018

Received in revised form

29.11.2018

Accepted 13.12.2018

Corresponding author:

M. Iakymchuk

E-mail:

mykolaiakymchuk.2016@ gmail.com

\begin{abstract}
Modern models of palletizer are made on the basis of functional mechatronic modules. The largest energy consumption in the modules for the accumulation of cargo layers is observed on a mobile platform. As drive units of such platforms electric motors, hydropneumatic cylinders can be used. The methods of energy recovery in electric and hydraulic drive units are known. But there is no information about the use of pneumatic accumulators for energy recovery in pneumatic drive units of mechatronic modules of step-by-step accumulation of cargo layers.

The purpose of the work is to develop a scheme and methods for calculation of pneumatic accumulators for energy recovery in pneumatic drive units of mechatronic modules of step-by-step accumulation of cargo layers on palletizer's moving platform.

The concept of the use of pneumatic accumulators for energy recovery in pneumatic drive units of functional mechatronic modules of step-by-step accumulation of layers of cargo of palletizers is substantiated.

The method for design of pneumatic accumulators for energy recovery in pneumatic drive units of functional mechatronic modules of step-by-step accumulation of cargo layers has been proposed based on the developed mathematical models. Various new schemes for load platforms of the module with energy recuperators on the basis of pneumatic accumulators have been proposed.

The results of the research are recommended for development of new effective palletizer's types.
\end{abstract}

\section{РЕКУПЕРАЦІЯ ЕНЕРГІЇ В ПНЕВМАТИЧНОМУ ПРИВОДІ ФУНКЦІОНАЛЬНОГО МЕХАТРОННОГО МОДУЛЯ НАКОПИЧЕННЯ ШАРІВ ВАНТАЖІВ}

\author{
М.В. Якимчук, О.М. Гавва, Л.О. Кривопляс-Володіна, В.М. Якимчук \\ Національний університет харчових технологій
}

Сучасні зразки обладнання для формування транспортних пакетів виготовляються на основі функиіональних мехатронних модулів. Найбільші енер- 
говитрати у модулях накопичення шарів вантажів на рухомій платформі. Приводами таких платформ можуть бути електродвигуни, гідропневмоциліндри. Відомі методики рекуперачії енергії в електро- та гідроприводах. Поряд із цим відсутня інформачія щодо використання пневматичних акумуляторів для рекуперачії енергї̈ в пневматичних приводах мехатронних модулів покрокового накопичення шарів вантажів.

Метою дослідження є розроблення схеми та методики розрахунку пневматичних акумуляторів для рекуперачії енергії в пневматичних приводах мехатронних модулів покрокового накопичення шарів вантажів на рухомій платформі пакетоформувальної машини.

Обтрунтовано конщепџію використання пневматичних акумуляторів для рекуперації енергії в пневматичних приводах функиіональних мехатронних модулів покрокового накопичення шарів вантажів пакетоформувальних машин.

На основі розроблених математичних моделей створено методику проектування пневматичних акумуляторів для рекуперації енергї в пневматичних приводах функиіональних мехатронних модулів покрокового накопичення шарів вантажів, а також запропоновано нові схемні рімення вантажних платформ модуля з рекуператорами енергї на базі пневматичних акумуляторів.

Результати досліджень можна рекомендувати для впровадження при проектуванні нових ефективних зразків пакетоформувальних машин.

Ключові слова: пакетоформувальна машина, мехатронний модуль, акумулятор, рекуперація, енергія, пневмопривід, вантаж.

Постановка проблеми. Розробка енергоощадливих технологій і машин $\epsilon$ одним із пріоритетних напрямків розвитку пакувальної індустрії на найближче десятиліття. 3 огляду на обсяги пакетних перевезень, які обчислюються сотнями мільярдів тонн на рік, можна стверджувати, що процес формування транспортних пакетів є масовим, а його автоматизація - актуальним завданням сьогодення.

Поява нових пакувальних матеріалів, продуктів харчування, логістичних схем призвели до суттєвого розширення форм і розмірів тари й упаковки, наявності додаткових функціональних елементів. Така тенденція суттєво вплинула на функціональні вимоги до сучасних конструкцій пакеформувальних машин - швидке переналагодження на інші розміри тарного вантажу або пакета, малі енерговитрати та невелику собівартість.

Реалізувати такі вимоги можна шляхом створення нових конструкцій пакетоформувальних машин. Важливим завданням при цьому є розроблення функціональних мехатронних модулів накопичення шарів вантажів 3 пневматичним приводом з функцією збереження енергії під час процесу формування транспортного пакета шляхом iї рекуперації та подальшим використанням для роботи інших мехатронних модулів пакетоформувальної машини.

Конструктивне виконання пакетоформувальних машин (ПФМ) відрізняється великою різноманітністю та залежить від особливостей технологічного процесу, властивостей і габаритних розмірів вантажів. Нове покоління ПФМ будується на основі функціональних мехатронних модулів. 
Використання вантажних платформ для вертикального переміщення вантажів у комплексах для пакетування тарних вантажів можливе при застосуванні будь-якого типу ПФМ.

Доведено [1], що рекуператорами енергії в конструкції функціонального мехатронного модуля покрокового накопичення шарів тарних вантажів можна підвищити енергетичну ефективність як самого модуля, так і всього пакеформувального комплексу загалом. Приводами таких модулів можуть бути електродвигуни, гідро- та пневмоциліндри, інколи пружинні комплекси. У разі застосування пневмоциліндрів як приводу у більшості вітчизняних $\mathrm{i}$ закордонних конструкцій ПФМ спостерігається використання пружиннопневматичних акумуляторів енергії, які працюють за таким принципом рекуперації енергії у вантажних платформах мехатронного модуля:

- переміщення платформи з вихідного верхнього положення в нижнє здійснюється за рахунок потенціальної енергії вантажів, накопиченої ними при здійсненні технологічного процесу;

- потенціальна енергія вантажів запасається в пружинно-пневматичному акумуляторі енергії;

- збережена в акумуляторі енергія використовується для повернення порожньої платформи в початкове положення;

- залишкова потенціальна енергія у вигляді стисненого повітря передається в пневмосистему для повторного використання.

Встановлено, що використання пружинно-пневматичних акумуляторів енергії для вантажних платформ неминуче призводить до виникнення коливальних процесів у механічній системі, які суттєво впливають на точність позиціювання платформи та продуктивність ПФМ.

Для ліквідації цього недоліку запропоновано використовувати функціональні мехатронні модулі покрокового накопичення шарів вантажів із пневматичним приводом, що мають пневматичний рекуператор енергії.

Аналіз останніх досліджень і публікацій. Дослідженням, пов'язаним 3 розвитком і проектуванням мехатронних модулів машин пакетування тарних вантажів, останнім часом приділяється велика увага [1]. Спостерігається тенденція взаємозв'язку між сучасними технологічними процесами пакування та мехатронними модулями як невід'ємною складовою розвитку автоматизованих і роботизованих ліній пакетування $[2 ; 3]$. Так, у [4; 5] наведені конструкції пакетоформувальних машин та методики розрахунків і підбору робочих органів функціональних модулів. В особливу групу можна об'єднати праці, у яких наведені методики дослідження витрат енергії на процеси пакетування [6;7]. Можливість застосування пружинного акумулятора в засобах вантажоперероблення досліджено у [8], де зазначено, що основною перевагою пружинного акумулятора $є$ простота конструкції та висока ефективність роботи модуля покрокового накопичення тарних вантажів. Однак у наведених працях відсутня інформація щодо використання пневматичних акумуляторів та їх застосування для рекуперації енергії в пневматичних приводах функціональних мехатронних модулів покрокового накопичення шарів вантажів.

Мета дослідження: розробити ефективну методику розрахунку та проектування пневматичних акумуляторів для рекуперації енергії в пневматичних 
приводах функціональних мехатронних модулів покрокового накопичення шарів вантажів пакетоформувальних машин.

Викладення основних результатів дослідження. На рис. 1 наведена схема запропонованого мехатронного модуля покрокового накопичення шарів вантажів із пневматичним приводом і рекуператором енергії на базі пневматичного акумулятора. Вантажна платформа 1 з'єднана зі штоком пневматичного циліндра 2 і переміщається у вертикальному напрямку по напрямній 3. На пневматичному циліндрі 1 встановлено датчики положення 4 і 5, один 3 яких (4) контролює верхнє положення поршня пневмоциліндра, а інший (5) нижнє положення поршня пневмоциліндра. На пневмоцилиндрі 1 встановлений фіксатор 6, який з'єднаний 3 виходом ресивера 7 через пневморозподільник 8. Ресивер 7 3'єднаний з пневмосистемою живлення. Безштокова порожнина пневмоциліндра 1 з'єднана з розподільниками 9.1, 9.2, які так само послідовно з'єднані з балонами 10.1, 10.2, розподільниками 11.1 , 11.2 і ресивером 7.

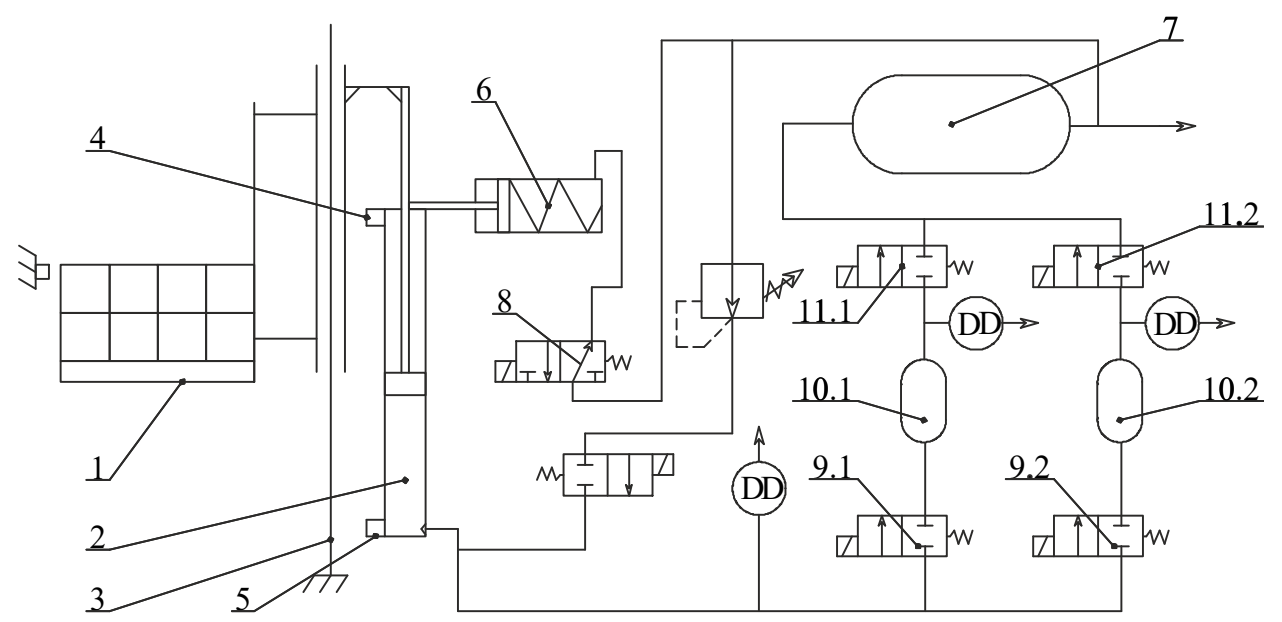

Рис. 1. Схема мехатронного модуля покрокового накопичення шарів вантажів із пневматичним приводом і рекуператором енергії на базі пневматичного акумулятора

Робота платформи здійснюється таким чином: у початковий момент часу порожня платформа піднята на максимальну висоту, фіксатор 6 утримує шток пневматичного циліндра 2. Розподільники 9.1, 9.2 і 13 знаходяться в закритому положенні. При такій конфігурації системи відбувається укладання перших трьох шарів вантажів. Після закінчення укладання першого шару вантажів пневматичний циліндр знімається 3 фіксатора і платформа під дією сили тяжіння вантажів переміщається до низу. У цей момент, коли платформа переміщається до низу на відстань, рівну висоті одного шару вантажів, у систему управління надходить сигнал із датчика 12 i фіксатор 6 знову зупиняє платформу. Укладання другого і третього шарів вантажів здійснюється таким же чином. При укладанні четвертого шару відкривається розподільник 9.1 і до пневмосистеми підключається додатковий балон 10.1. Завдяки 
підключенню цього балона при опусканні платформи, вона отримує додаткове переміщення, яке дає можливість привести залежність переміщення платформи від маси вантажів на ній до лінійної. При укладанні п’ятого шару вантажів розподільник 9.2 переходить у відкритий стан і до пневмосистеми підключається додатковий балон 10.2. Підключення цього балона також дає можливість забезпечити лінійну характеристику системи. Укладання шостого шару вантажів здійснюється без переміщення платформи. При цьому розподільники 9.1 і 9.2 переходять у закритий стан, а розподільники 11.1 і $11.2-$ у відкритий стан, тобто балони з'єднуються з ресивером 7. Після вирівнювання тиску в ресивері 7 та балонах 10.1 і 10.2, вони відключаються від ресивера. Паралельно 3 процесом перемикання балонів відбувається зняття сформованого транспортного пакета з платформи, зафіксованої в нижньому положенні.

На рис. 2 наведена спрощена схема платформи 3 вантажами на першому етапі роботи системи. Платформа 1 з'єднана зі штоком пневмоциліндра 2 , до якого на певних етапах переміщення платформи можуть бути послідовно підключені балони 3. На платформу укладаються шари вантажів.

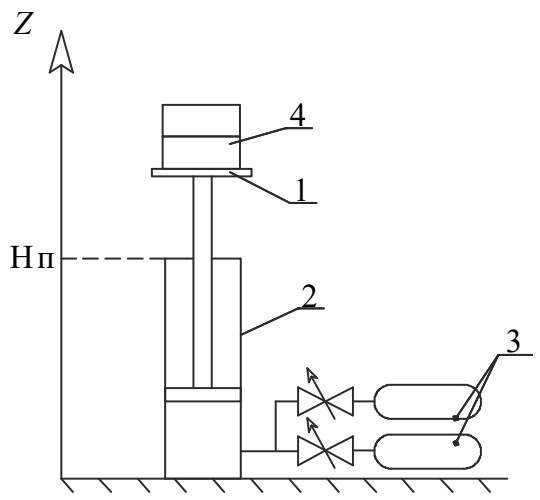

Рис. 2. Розрахункова схема пневмоциліндра з послідовним підключенням балонів

При укладанні кожного шару і зняття платформи з фіксаторів переміщення платформи можна описати рівнянням енергетичного балансу системи:

$$
m g_{i} Z=\frac{m g \dot{Z}_{i}^{2}}{2}+P_{i-1} V_{i-1} \ln \left(\frac{P_{i}}{P_{i-1}}\right),
$$

де $m$ - маса одного шару вантажів; $Z i$ - поточна відстань переміщення платформи під дією ваги і-го шару вантажів; $P_{i-1}$ - тиск у пневматичному циліндрі після переміщення $i-1$-го шару вантажів; $V_{i-1}-$ об’єм безштокової порожнини пневматичного циліндра, який встановився після переміщення $i-1$ шару вантажів; $P_{i}$ - тиск у безштоковій порожнині пневмоциліндра після укладання $i$-го шару.

Прирівнявши швидкість платформи з вантажами до нуля $\dot{Z}_{i}=0$, рівняння (1) можна записати у вигляді: 


$$
m g h_{i}=P_{i-1} V_{i-1} \ln \left(\frac{P_{i}}{P_{i-1}}\right),
$$

де $h_{i}$ - максимальне переміщення платформи до низу під дією ваги $i$-го шару.

Тиск $P_{i}$ на кожному кроці переміщення визначається масою вантажів на платформі:

$$
P_{i}=\frac{\left(i m+m_{n л}\right) g}{S}+P_{a m м},
$$

де $S$ - площа поршня пневматичного циліндра.

Для визначення площі поршня пневматичного циліндра задамося максимальним тиском $P_{k}$ в системі, коли укладені всі шари вантажів, крім останнього (укладання останнього шару вантажів проводиться без переміщення платформи). Тоді площу поршня пневмоциліндра можна визначити, записавши рівняння (3) у вигляді:

$$
P_{k}=\frac{\left((N-1) \cdot m+m_{n л}\right) g}{S}+P_{a m M},
$$

де $N$ - кількість шарів вантажу в пакеті.

Звідки:

$$
S=\frac{\left((N-1) \cdot m+m_{n л}\right) g}{P_{k}-P_{a m \mu}} .
$$

Для переміщення платформи під дією першого шару вантажів рівняння (2) набуде вигляду:

$$
m g h_{1}=P_{0} V_{0} \ln \left(\frac{P_{1}}{P_{0}}\right),
$$

де $P_{0}, V_{0}$ - початкові тиск і об'єм у безштоковій порожнині пневмоциліндра.

Для забезпечення стабілізації робочої поверхні укладання вантажів доцільно вибрати початковий тиск у пневматичному циліндрі таким чином, щоб максимальне переміщення під дією ваги першого шару відбувалося б на висоту, рівну висоті одного шару вантажу. Прийнявши стискання повітря в циліндрі ізотермічним і враховуючи, що для такого процесу справедливо співвідношення (2), рівняння (6) може бути записано у вигляді:

$$
m g h_{u}=P_{0} V_{0} \ln \left(\frac{V_{0}}{V_{0}-S h_{u}}\right) \text {. }
$$

Звідки:

$$
P_{0}=\frac{m g h_{u}}{V_{0} \ln \left(\frac{V_{0}}{V_{0}-S h_{u}}\right)}
$$

Результати аналітичного дослідження переміщення платформи за наведеною методикою наведено на рис. 3 . 


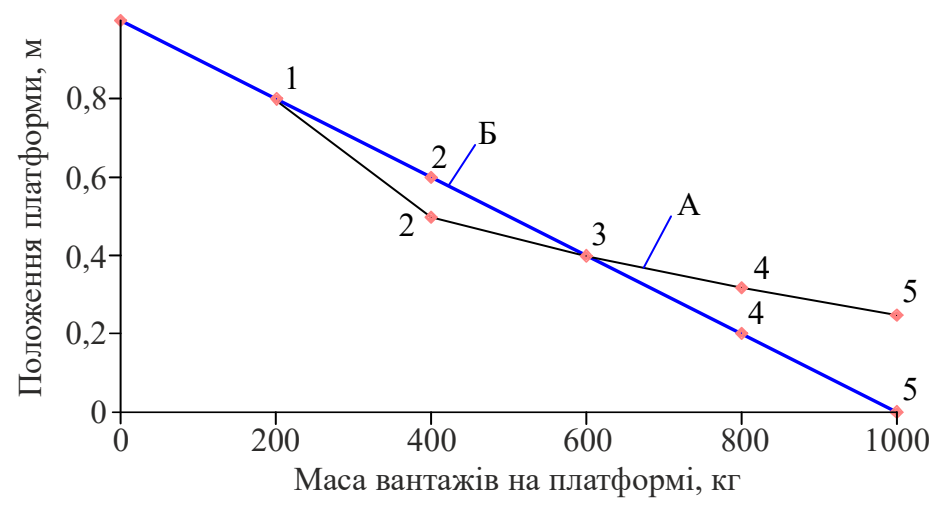

Рис. 3. Графік залежності переміщення платформи від маси вантажів на ній при відключених балонах і початковому тиску $\boldsymbol{P}_{01}$

Крива А — це граф положень платформи при іï послідовному навантаженні шарами вантажів для пакета 3 параметрами: упаковка 3 харчовим продуктом форми паралелепіпеда 3 розмірами 200 мм $\times 300$ мм $\times 200$ мм; характеристики транспортного пакета, сформованого з таких упаковок: шість шарів упаковок по шістнадцять вантажів у кожному шарі. Крива Б - це граф переміщень платформи з пружинно-пневматичним акумулятором для такого ж транспортного пакета, який характеризується лінійною залежністю положення платформи від кількості шарів вантажу на ній.

3 графіка видно, що за таких умов залежність положення платформи від маси вантажів на ній практично лінійна при укладанні перших трьох шарів вантажу. Однак при укладанні четвертого і п’ятого шарів вантажів переміщення поршня, а отже, і платформи буде недостатнім. Для приведення до лінійної залежності положення платформи від кількості укладених на неї шарів вантажів при укладанні четвертого і п'ятого шарів запропоновано послідовно підключати до системи додаткові об'єми $V_{b 1}$ та $V_{b 2}$.

Після переміщення платформи під дією ваги третього шару вантажів i встановлення iї на фіксатори відбувається з'єднання пневматичного циліндра 3 першим додатковим балоном. При цьому відбувається процес, що можна описати рівнянням

$$
P_{3} V_{3}+V_{b 1} P_{b 0}=P_{3}^{*}\left(V_{3}+V_{b 1}\right),
$$

де $P_{3}, V_{3}$ - тиск і об'єм безштокової порожнини циліндра після укладання третього шару вантажів; $P_{b 0}-$ початковий тиск у додаткових балонах; $P_{3}^{*}-$ тиск, який встановлюється в безштоковій порожнині пневмоциліндра.

Після укладання четвертого шару і зняття платформи 3 фіксаторів переміщення платформи з вантажами до низу описується рівнянням:

$$
m g h_{3}=P_{3}^{*}\left(V_{3}+V_{b 1}\right) \ln \frac{V_{3}+V_{b 1}}{V_{3}+V_{b 1}-m g h_{3}},
$$

де $h_{3}-$ необхідне вертикальне переміщення платформи після укладання четвертого шару (відрізок 4-4, А на рис. 3). 
Після завершення переміщення платформи під дією ваги четвертого шару вантажів і встановлення платформи на фіксатор відбувається з'єднання безштокової порожнини пневмоциліндра 3 другим додатковим балоном. Цей процес можна описати рівнянням:

$$
P_{4}\left(V_{4}+V_{b 1}\right)+V_{b 2} P_{b 0}=P_{4}^{*}\left(V_{4}+V_{b 1}+V_{b 2}\right),
$$

де $V_{4}-$ об'єм безштокової порожнини циліндра після переміщення платформи під дією четвертого шару вантажів; $P_{4}^{*}$ - тиск у безштоковій порожнині пневмоциліндра, а також у першому і другому додаткових балонах після приєднання другого балона до пневмоциліндра.

Після укладання п'ятого шару і зняття платформи 3 фіксаторів переміщення платформи з вантажами до низу описується рівнянням:

$$
m g h_{\mathrm{II}}=P_{4}^{*}\left(V_{4}+V_{b 1}+V_{b 2}\right) \ln \frac{V_{4}+V_{b 1}+V_{b 2}}{V_{b 1}+V_{b 2}} .
$$

Після завершення формування пакета починається наступний етап роботи системи, що характеризується відключенням балонів від пневмоциліндра та ïx з'єднанням із ресивером. На рис. 4 наведена спрощена схема пневмосистеми для побудови математичної моделі.

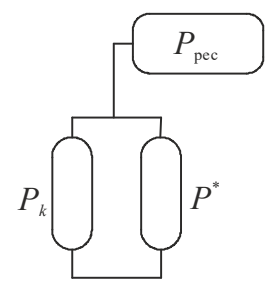

Рис. 4. Пневмосистема на етапі з'сднання балонів із ресивером

Процес перетікання газу з балонів у ресивер описується рівнянням:

$$
P_{k}\left(V_{b 1}+V_{b 2}\right)+P_{\mathrm{pec}} V_{\mathrm{pec}}=P^{*}\left(V_{b 1}+V_{b 2}+V_{\mathrm{pec}}\right),
$$

де $P_{\text {рес }}, V_{\text {рес }}$ - початковий тиск і об'єм у ресивері відповідно; $P^{*}-$ тиск у балонах і ресивері під час їх з'єднання.

Після відключення балонів від ресивера залишковий тиск у них буде рівним $P^{*}$, проте, якщо він перевищує або менший за початковий тиск в балонах $P_{b 0}$, що вимагається для пошарового переміщення платформи, то виникне потреба стравлювати або, навпаки, накачувати тиск у балонах до значення $P_{b 0}$. Тому раціонально побудувати систему таким чином, щоб тиск $P_{b 0}$, який встановлюється в балонах після з'єднання 3 ресивером, був початковим. Прирівнявши $P_{b 0}=P^{*}$ із виразу (13), отримуємо:

$$
P_{b 0}=\frac{P_{\mathrm{pec}}\left(V_{b 1}+V_{b 2}\right)+P_{\mathrm{pec}} V_{\mathrm{pec}}}{\left(V_{b 1}+V_{b 2}+V_{\mathrm{pec}}\right)} .
$$

Отже, рівняння (9)-(12), (14) можуть бути зведені в систему рівнянь, 3 якої можна визначити $V_{b 1}, V_{b 2}, P_{b 0}$ : 


$$
\left\{\begin{array}{l}
m g h_{3}=\left(P_{3} V_{3}+V_{b 1} P_{b 0}\right) \cdot \ln \frac{V_{3}+V_{b 1}}{V_{3}+V_{b 1}-S h_{3}} ; \\
m g h_{\mathrm{II}}=\left(P_{4}\left(V_{4}+V_{b 1}\right)+V_{b 2} P_{b 0}\right) \cdot \ln \frac{V_{4}+V_{b 1}+V_{b 2}}{V_{b 1}+V_{b 2}} ; \\
P_{k}\left(V_{b 1}+V_{b 2}\right)+P_{\mathrm{pec}} V_{\mathrm{pec}}=P_{b 0}\left(V_{b 1}+V_{b 2}+V_{\mathrm{pec}}\right) .
\end{array}\right.
$$

Система рівнянь (15) вирішується чисельними методами для заданих параметрів вантажу й транспортного пакета.

Для визначення об'ємів балонів у загальному вигляді приймаємо таку модель укладання четвертого та п'ятого шарів вантажів: розрахуємо спочатку переміщення $\Delta Z_{i 1}$ платформи під дією вантажів при закритому балоні, а потім розрахуємо іï додаткове переміщення $\Delta Z_{i 2}$ після відкриття балона. При цьому сумарне переміщення для цього шару $\Delta Z_{i}$ відоме. Для четвертого шару воно визначається з відомого переміщення третього шару, а для п'ятого шару складає висоту одного шару вантажів. Незважаючи на прийняті припущення, за всіх інших умов включення балонів кінцеве значення переміщення платформи буде однаковим, незалежно від вибраної моделі.

При укладанні четвертого шару вантажів без додаткового балона в системі відбувається стискання газу під дією ваги вантажу. Цей процес описується рівнянням енергетичного балансу системи:

$$
m_{\mathrm{II}} \cdot g \cdot \Delta Z_{4.1}=P_{3} V_{3} \ln \left(\frac{P_{4}}{P_{3}}\right),
$$

де $\Delta Z_{4.1}$ - переміщення платформи при укладанні четвертого шару вантажів при закритому балоні.

Об'єм безштокової порожнини пневмоциліндра після переміщення платформи без підключення балонів дорівнює:

$$
V_{4.1}=V_{3}-S \cdot \Delta Z_{4.1} \text {. }
$$

3 урахуванням рівняння (16) можна записати:

$$
V_{4.1}=V_{3}-\frac{S \cdot P_{3} \cdot V_{3} \ln \left(\frac{P_{4}}{P_{3}}\right)}{m_{\mathrm{m}} \cdot g} .
$$

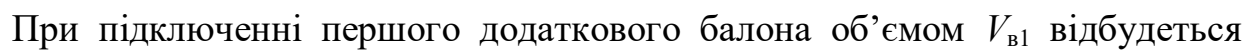
вирівнювання тиску у безштоковій порожнині пневматичного циліндра i першого додаткового балона до значення $P_{4}$, який визначається масою вантажів на платформі. Цей процес буде супроводжуватись переміщенням платформи до низу на висоту $\Delta Z_{4.2}$. Рівняння, що описує поведінку системи в цей момент, можна записати у вигляді:

$$
P_{4} V_{4.1}+V_{\mathrm{B} 0} \cdot V_{\mathrm{B} 1}=P_{4}\left(V_{3}-S\left(\Delta Z_{4.1}+\Delta Z_{4.2}\right)+V_{\mathrm{B} 1}\right) .
$$


Оскільки

$$
S h_{\text {шा }}=V_{3}-S\left(\Delta Z_{4.1}+\Delta Z_{4.2}\right),
$$

To

$$
V_{\mathrm{B} 1}=\frac{P_{4}\left(V_{4.1}-S h_{\text {шा }}\right)}{P_{1}-P_{\text {в0}}} .
$$

При укладанні п'ятого шару вантажів без підключення другого додаткового балона перший балон залишається підключеним до безштокової порожнини пневмоциліндра.

Рівняння енергетичного балансу може бути записано:

$$
m_{\text {ш }} \cdot g \cdot \Delta Z_{5.1}=P_{4} V_{4} \ln \left(\frac{P_{5}}{P_{4}}\right) .
$$

Об'єм безштокової порожнини пневмоциліндра після переміщення п'ятого шару без підключення другого додаткового балона дорівнює:

$$
V_{5.1}=S h_{\text {шा }}-S \Delta Z_{4.1}
$$

3 урахуванням рівняння (22) можна записати:

$$
V_{5.1}=S h_{\mathrm{\amalg I}}-\frac{S \cdot P_{4} \cdot V_{4} \ln \left(\frac{P_{5}}{P_{4}}\right)}{m_{\mathrm{m}} \cdot g} .
$$

Після відкриття другого балона рівняння вирівнювання тиску має вигляд:

$$
P_{5}\left(V_{5.1}+V_{\text {в. } 1}\right)+P_{\text {в } 0} \cdot V_{\text {в } 2}+P_{5}\left(V_{\text {в. } 1}+V_{\text {в. } 2}\right),
$$

звідки

$$
V_{\mathrm{B} .2}=\frac{P_{5} \cdot V_{5.1}}{P_{5}-P_{\mathrm{B} 0}}
$$

Після відключення балонів ресивер через регулятор тиску з'єднується 3 пневмоциліндром і платформа знову підіймається в початкове положення. При цьому в циліндрі створюється тиск $P_{01}$.

Щоб знайти тиск у ресивері після того, як тиск у циліндрі буде $P_{01}$, запишемо вираз:

$$
P_{0.1}^{*} \cdot S H+V_{\mathrm{pec}} \cdot P_{\mathrm{pec}}^{*}=P_{0.1} \cdot S H+V_{\mathrm{pec}} \cdot P_{\mathrm{pec} . k}
$$

звідки

$$
P_{\text {pec. } k}=\frac{P_{0.1}^{*} \cdot S H+V_{\mathrm{pec}} \cdot P_{\mathrm{pec}}^{*}-P_{0.1} \cdot S H}{V_{\mathrm{pec}}},
$$

де $P_{\text {pec. } k}$ - тиск у ресивері в кінці циклу.

На рис. 5 наведена схема зміни тиску в системі функціонального мехатронного модуля накопичення шарів вантажів із пневматичним приводом на 
різних етапах іiі роботи. Відповідно до схеми встановлено, що в результаті раціонального вибору параметрів окремих компонентів системи цикл зміни тиску в системі при укладанні кожного пакета $\epsilon$ замкнутим. Таким чином вдається уникнути втрат енергії, обумовлених необхідністю стравлювати або підкачувати тиск у балонах і пневмоцилиндрі для забезпечення початкового значення тисків. Передбачається, що підкачування тиску до значення $P_{0}$ в пневмоцилиндрі та $P^{*}$ в балонах відбувається тільки один раз на початку роботи системи при формуванні першого пакета.

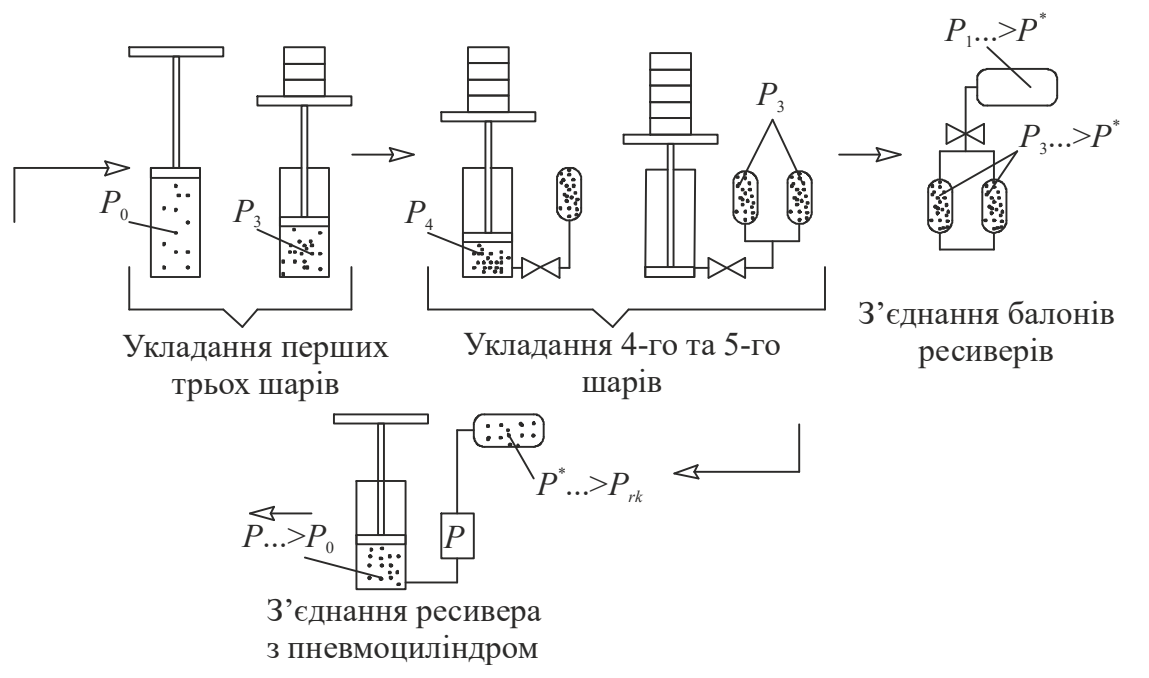

Рис. 5. Схема зміни тиску в системі функціонального мехатронного модуля накопичення шарів вантажів із пневматичним приводом на різних етапах ї̈ роботи

Визначимо швидкість платформи при іï переміщенні до низу. Для цього запишемо рівняння енергетичного балансу системи. Потенціальна енергія платформи із вантажем при іï переміщенні до низу переходить у кінетичну енергію платформи із вантажем, а також у роботу, що витрачається на стискання газу в безштоковій порожнині пневмоціліндра. А тому без врахування дисипативних сил рівняння енергетичного балансу системи можна записати:

$$
E_{\Pi}=E_{\mathrm{\kappa}}+A_{\text {ст }},
$$

де $E_{\Pi}-$ потенціальна енергія платформи із вантажем; $E_{\text {к }}-$ кінетична енергія платформи із вантажем; $A_{\text {ст }}$ - робота стискання.

При ізотермічному процесі роботу $A_{\text {ст }}$ можна визначити:

$$
A_{\text {cr }}=P_{0} \cdot V_{0} \cdot \ln \left(\frac{V_{0}}{V}\right) .
$$

Тоді можна записати, що:

$$
m g Z=\frac{m \dot{Z}^{2}}{2}+P_{0} S H \cdot \ln \left(\frac{H}{H-Z}\right) .
$$


Із рівняння (31) визначимо швидкість руху платформи:

$$
\dot{Z}=\sqrt{2\left(g Z-\frac{P_{0} S H}{m} \ln \left(\frac{H}{H-Z}\right)\right)} .
$$

Тривалість переміщення платформи до низу можна визначити за формулою:

$$
t_{i}=\int_{Z_{0}}^{Z_{i}} \frac{1}{v(Z)} \cdot d Z
$$

За допомогою кінематичних і часових параметрів узгоджується продуктивність мехатронного модуля та циклова діаграма роботи всього комплексу пакетування.

\section{Висновки}

На основі проведених аналітичних досліджень розроблена схема та методика розрахунку пневматичних акумуляторів для рекуперації енергії в пневматичних приводах функціональних мехатронних модулів покрокового накопичення шарів вантажів. Встановлено, що потенціальна енергія вантажів переходить в енергію стисненого повітря, частина якої витрачається на піднімання порожньої платформи, а інша частина передається в пневмосистему пакетувального комплексу. Основною перевагою такої конструкції порівняно 3 пружно-пневматичними акумуляторами енергії - малий час перехідних процесів і відсутність багаторазового перетворення енергії з одного виду в інший. Результати дослідження можна рекомендувати для впровадження при проектуванні нових конструкцій функціональних мехатронних модулів покрокового накопичення шарів вантажів з пневматичним приводом.

\section{Література}

1. Гавва О.М., Беспалько А.П., Волчко А.І., Кохан О.О. Пакувальне обладнання: підруч. для студ. ВНЗ. Київ: ІАЦ Упаковка, 2010. 746 с.

2. Проектирование и разработка промышленных роботов: книга / С.С. Аншин и др.; Под общ. ред. Я. А. Шифрина, П. Н. Белянина. Москва: Машиностроение, 1989. 272 с.

3. Васильев А.Л. Модульный принцип формирования техники: книга. Москва: Издательство стандартов, $1989.240 \mathrm{c}$.

4. Васильев А.Л. Модульный принцип в судостроении. Стандарты и качество. 1983. № 1. C. $8-14$.

5. Пакетоформирующие машины: книга / А.П. Кривопляс и др. Москва: Машиностроение, $1982.239 \mathrm{c}$.

6. Пальчевський Б.О. Автоматизація технологічних процесів (виготовлення і пакування виробів): навч. посіб. Львів: Світ, 2007. 392 с.

7. Гавва О.М., Беспалько А.П., Волчко А.І., Пакувальне обладнання. Обладнання для обробки транспортних пакетів: підруч. для студ. ВНЗ. Київ: ІАЦ Упаковка, 2006. 96 с.

8. Жавнер М.В. Методы расчета и проектирования исполнительных устройств робототехнических систем на базе пружинных механизмов: дис. канд. техн. наук: 02.05.02. Унив. низкотемп. и пищ. технол. Санкт-Петербург, 2003. 132 с.

9. Крутіков Г.А. Синтез енергозберігаючих гідропневмоагрегатів: автореф. дис. на здобуття наук. ступеня док. техн. наук: спец. 05.05.17 / Національний технічний університет «Харьківський політехнічний інститут». Харків, 2011.35 с.

10. Евдокимов А.И., Осипов В.А. Схемы энергосбережения для пневматических приводов Фундаментальные и прикладные проблемы совершенствования пориневых двигателей. 2003. C. $364-365$. 